\title{
Growth of Lactococcus lactis subsp lactis in Milk Under Control of Culture Acidity
}

\author{
Kamel, Dalia G.; Nanis H. Gomma; Dina M. Osman and A.I. Hassan
}

Dairy Science Department, Faculty of Agriculture, Assiut University. Received on: 20/11/2017 Accepted for publication on: 10/12/2017

\begin{abstract}
The effect of control of culture acidity on growth kinetics of one homofermentative strains of lactic acid bacteria, namely., Lactococcus lactis subsp lactis was evaluated. The bacterial growth was estimated on the base of colony forming units, developed titratable acidity and incubation time .Sterilized skim milk was used as a medium with incubation at $34^{\circ} \mathrm{C}$.

Sampling had been carried out at zero time and each 2 hours intervals. After each sampling, a calculated volume of a liquid of $0.1 \mathrm{~N}$ sodium hydroxide was added to the culture to adjust the acidity of the remaining volume of the cultures to its initial value at zero time.
\end{abstract}

The obtained results indicated that:

1- When Lactococcus lactis subsp lactis grown under control of culture acidity lag phase was not observed.

2- Significant effect of acidity control was noticed on the growth rate. Exponential phase of growth was between $2^{\text {ed }}$ and $12^{\text {th }}$ hour of incubation. However, the same culture being grown with control of culture acidity the exponential phase of growth was at interval of time from zero up to $24^{\text {th }}$ hour of incubation.

3 - The maximum cell population in case of the control sample was $124 \mathrm{x}$ $10^{5} \mathrm{CFU} / \mathrm{ml}$ after 12 hours of incubation. The corresponding values when growth was under control of culture acidity was by a maximum cell population of $35 \times 10^{6}$ $\mathrm{CFU} / \mathrm{ml}$ after 32 hour of incubation.

Keywords: Lactic acid bacteria, titratable acidity, colony count, culture acidity control, Mrs Media.

\section{Introduction}

Lactic acid bacteria are a group of gram- positive, non spore forming, an aerobic or facultative aerobic cocci or rods, which produce lactic acid as one of the main fermentation products of the carbohydrates metabolism. Lactic acid bacteria play a critical role in food production and health maintenance (Quinto et al., 2014).

During milk fermentation processes, lactic acid bacteria are exposed to various environmental stress conditions, such as temperature fluctuations, acidity, $\mathrm{pH}$ and decrease of available nutrients. Some of these conditions will often coincide.
Like other bacteria, lactic acid bacteria have evolved intricate stress (Van de Guchte et al., 2002). Furthermore, studying the effects of their environmental parameters on growth kinetics should provided useful informations concerning the physiology of these microorganisms (Ismail, 1991). The inhibitory effect of lactic acid on the growth of lactic acid bacteria has been definitively provided by Fridman and Gaden (1970). In addition, they found that when Lactococcus lactis subsp lactis grown at a constant $\mathrm{pH}$, lag time being shorter and a significant effect of $\mathrm{pH}$ control was noticed on the growth rate. 
Charalampopulos et al. (2002) studied the factors affecting growth of lactic acid bacteria during the exponential phase $(10-12 \mathrm{~h})$, and found that the most decisive factor affecting the bacterial growth during this period is medium $\mathrm{pH}$, which at this time ranged from 3.44 to 3.77 in all tested Lactobacillus species and this result in reduction in bacterial growth, not depletion of nutrients, as only $17-43 \%$ of sugars were consumed by the end exponential phase.

Vermeulen et al. (2007) found that combination of different environmental factors can significantly affect the growth of Lactobacillus spp. They showed that addition of lactic acid can only be beneficial when no or low concentration of acetic acid are present. Otherwise, inhibition is mainly caused by the combinatory effects of $\mathrm{pH}$ and acetic acid, beside it was observed that at higher amounts of lactic acid, the influence of $\mathrm{pH}$ on the growth probability is more pronounced than in the absence of lactic acid. Possible explanation of this phenomenon can be due to the increased buffering capacity of the media in the presence of lactic acid.

The aim of this investigation was to study the growth and activity of Lactococcus lactis subsp lactis in milk with and without control of culture acidity and analysis of growth kinetics for clear understanding of the physiology of the given organism.

\section{Material and Methods Materials:}

1- Milk:

Buffalo milk used in this study was obtained from Faculty of Agriculture, Assiut Uni. herd, morning milking. As soon as milk was arrived to the laboratory it was skimmed by using Alfa- Laval separator operated at speed of $16000 \mathrm{rpm}$.
Skim milk was distributed into 1 L conical flasks, each flask contained $750 \mathrm{ml}$ skim milk, conical flasks containing skim milk were sterilized by using autoclave operated at $121^{\circ} \mathrm{C} / 10$ minutes under pressure of $\left(15 \mathrm{lph} / \mathrm{inc}^{2}\right)$.

\section{2- Bacteria:}

- Lactococcus lactis subsp lactis was employed for this study. It was obtained from the Culture Collection of Botany Department, Faculty of Science, Assiut University.

All microorganisms were routinely maintained in sterile litmus milk fortified with $0.1 \%$ peptone and stored at $5-7^{\circ} \mathrm{C}$.

For the preparation of the inocula, the procedure described by Hassan et al. (1989) was adopted. From each stored bacterial culture, a 1/10 dilutions were made in $500 \mathrm{ml}$ conical flasks each one contained from150-250 ml sterilized skim milk.

After overnight incubation at $34^{\circ} \mathrm{C}$, the first non-coagulated flask in which the bacteria was expected to be in the exponential phase of growth was used for inoculating the experimental flasks.

Inoculation has been carried out using certain volumes from the first non-coagulated flask to achieve about $10^{5} \mathrm{CFU} / \mathrm{ml}$ when inoculated in the experimental flasks.

\section{3- Growth media:}

MRS media was used in this study, plate counts were prepared on MRS agar, as described in Difco manual (1998).

\section{4- Cultural conditions:}

The obtained cultures was propagated under two different conditions i.e.:

1- Control (with control of culture acidity).

2- Treatment (under control of culture acidity).

\section{Methods:}


- Effect of control of culture acidity on the growth rate of lactic acid bacteria:

To study the effect of control of culture acidity on the growth rate of bacteria. Two of $1 \mathrm{~L}$ conical flask each one contained $750 \mathrm{ml}$ sterilized skim milk were inoculated separately by volume of the starter culture to give about $10^{5} \mathrm{CFU} / \mathrm{ml}$ at zero time. Conical flasks were incubated in a water bath at $34^{\circ} \mathrm{C}$.

Cultures were propagated under two different conditions. The first flask was used as a control while the second was used to study the effect of control of culture acidity on the growth rate of studied bacteria.

At each sampling time to the second flask calculated volumes of aliquot of $1 \mathrm{~N} \mathrm{NaOH}$ was added to the culture to adjust the acidity of the remaining volume of cultures to its initial value at zero - time.

\section{- Sampling}

At the time of inoculation, zero time and each two hours intervals up to two hours after milk coagulation or up to 48 hours, a $15 \mathrm{ml}$ aliquots of each culture was aseptically withdrawn in 25 $\mathrm{ml}$ sterilize conical flask.

$1 \mathrm{ml}$ of the aliquots was aseptically withdrawn in a test tube containing $9 \mathrm{ml}$ sterilized distilled water to give the first dilution $1 / 10$ for the bacteriological analysis $\left(10^{-1}\right)$ then it was shaked gently for 30 second and used for the preparation of other dilutions $\left(10^{-2}, 10^{-3}, 10^{-4}, 10^{-5}, 10^{-6}\right)$. MRS agar media was used in the present study. Inoculated petri dishes were incubated at $34^{\circ} \mathrm{C}$ for 72 hours.

Colonies were determined by direct visual inspection.

Total viable counts were counted and was expressed to the corresponding $\log 10$ values $(\log \mathrm{CFU} / \mathrm{ml})$.

Acid development was followed by determining the acidity of samples using N/9 NaOH solution. The developed titratable acidity was calculated as previously described by Cogan (1978).

\section{Results and Discussion}

When lactose utilizing bacteria such as Lactococcus lactis subsp lactis grown in medium containing lactose, i.e., milk, acidity of the medium went down gradually. Therefore, it seemed of interest to investigate the effect of acidity control of the culture on the bacterial growth, without control of culture acidity, cessation of growth of Lactococcus lactis subsp lactis occurred concomitantly with the acidification of the culture (Sinclaid and Stokes, 1962).

The effect of acidity control on the length of lag time varied according to the treatment as shown in Table 1 and Figures 1 and 2.

Lag time in case of control sample was ranged from 0 to 2 hours of incubation, On the other hand, lag time was markedly remarkably changed by acidity control of the culture; where lag phase was not observed. These results are in good agreement with those obtained by Bergere (1968), Richardson et al. (1983) and Ismail (1991).

Results in Table 1, Figures 1 and 2 , indicate that when Lactococcus lactis subsp lactis was grown in sterilized skim milk, acidity of the medium was raised gradually. Cessation of growth occurred concomitantly with acidification rate of the culture during the period from $24^{\text {th }}$ to $28^{\text {th }}$ hour of incubation; while the culture acidity was raised from 0.53 to $0.60 \%$, the corresponding values for colony forming unites were $126 \times 10^{5}$ and $122 \times 10^{5} \mathrm{CFU} / \mathrm{ml}$ respectively.

Several explanations have been offered for the cessation of growth in bacterial cultures. These include accumulations of toxic metabolic products, exhaustion of essential nutrients and 
oxygen, development of an unfavorable acidity. These results are in agreement with those obtained by Ismail (1991) who found that when Lactococcus lactis subsp lactis which is protease positive and its negative variant grown under control of culture acidity. The cell mass was several times as late as when grown without control of acidity and he mentioned that when the protease positive variant grown without and with control of acidity the maximum number of colony forming units after $9^{\text {th }}$ hour of incubation $8.7 \times 10^{8}$ and $2.4 \times 10^{9}$ $\mathrm{CFU} / \mathrm{ml}$. The corresponding values for the protease negative variant were $7.6 \mathrm{x}$ $10^{7}$ and $1.9 \times 10^{8} \mathrm{CFU} / \mathrm{ml}$.

After 24 hour of incubation, the growth rate continued but by a slower rate mainly because of accumulations of toxic metabolic products and exhaustion of essential nutrients.

A number of studies have been carried out to establish the relationship between the growth rate of a microorganisms and the corresponding culture acidity. Two conflecting results have been reported; those in which the growth rate and acid production appear to be independent and these in which growth rate and acid production varied in the same directions and rate (Ismail, 1991).

The obtained results showed that, when Lactococcus lactis subsp lactis grown in sterilized skim milk the rate of increase in colony forming units and the rate of increase in developed titratable acidity had the same trend.

On the other hand, samples grown with control of culture acidity, the maximum increase in culture acidity was observed during the period from $12^{\text {th }}$ hour up to 24 hour of incubation where acidity was increased from $0.23 \%$ up to $0.43 \%$.

These results are in agreement with those obtained by Ismail (1991) for prt variant, and conflicted with those for $\mathrm{prt}^{+}$variant in case of $\mathrm{pH}$ control.

The obtained results for the growth rates at different conditions of acidity are shown in Table 1 and 2 and Figures 1 and 2. In case of control sample, the exponential phase of growth was at interval of time from the $2^{\text {ed }}$ up to $24^{\text {th }}$ hour of incubation reaching a maximum population of $126 \times 10^{5}$ $\mathrm{CFU} / \mathrm{ml}$. However, when growth was with control of acidity, the exponential phase of growth was at interval of time from 0 up to 26 hour of incubation with maximum cell population of $250 \times 10^{5}$ $\mathrm{CFU} / \mathrm{ml}$.

These observation are in agreement with those found for two other homofermentative strains, Lactobacillus helveticus (Roy et al. 1986) and Pediococcus pentosaceus (Bilckstad and Molin, 1981).

In the case of control sample, the growth curve started to reach the stationary phase between $24^{\text {th }}$ to $28^{\text {th }}$ hour because of the increase of acidity and consumption of nutrients in the media. The number of colonies was $126 \times 10^{5}$ $\mathrm{CFU} / \mathrm{ml}$ at $24^{\text {th }}$ hour, which became $124 \times 10^{5} \mathrm{CFU} / \mathrm{ml}$ at $26^{\text {th }}$ hour then, it reached $122 \times 10^{5} \mathrm{CFU} / \mathrm{ml}$ at $28^{\text {th }}$ hour and the curve was dropped in $30^{\text {th }}$ hour and started to reach the declined phase because it was affected with, increase in acidity, cell secretions, consumption of nutrients in the media, and accumulation of food transformation products. However, in the case of Lactococcus lactis subsp lactis with control of acidity, the growth rate increased in a noticeable way to be $150 \times 10^{5} \mathrm{CFU} / \mathrm{ml}$ at $24^{\text {th }}$ hour. This upsurge continued rapidly until $34^{\text {th }}$ hour.

Several studies have been carried out to establish the relationship between the growth rate of a microorganism and the corresponding increase in 
culture acidity Britz et al. (1980) and Bossyut (1982).

In present study, both the growth rates as measured by the rate of increase in colony forming unites and developed titratable acidity had the same trend throughout the experiment (Figures 1 and 2). On other hand, the obtained results indicated that Lactococcus lactis subsp lactis propagated in sterilized skim milk with control of culture acidity grown by higher growth rate as measured by the rate of increase in CFU or DTA in comparing with the same variants being grown without culture acidity control.

Table 1. Rate of increase of colony count (CFU/ml) and $\log \mathrm{CFU} / \mathrm{ml}$ during growth of Lactococcus lactis subsp lactis cultivated in sterilized skim milk with and without control of culture acidity at $34^{\circ} \mathrm{C}$.

\begin{tabular}{|c|c|c|c|c|}
\hline \multirow{2}{*}{$\begin{array}{c}\text { Sampling } \\
\text { time (hour) }\end{array}$} & \multicolumn{2}{|c|}{ Control } & \multicolumn{2}{c|}{ With control of culture acidity } \\
\cline { 2 - 5 } & CFU / ml & Log CFU / ml & CFU / ml & Log CFU / ml \\
\hline $\mathbf{0}$ & $30 \times 10^{4}$ & 5.47 & $35 \times 10^{4}$ & 5.54 \\
\hline $\mathbf{2}$ & $60 \times 10^{4}$ & 5.77 & $65 \times 10^{4}$ & 5.81 \\
\hline $\mathbf{4}$ & $75 \times 10^{4}$ & 5.87 & $120 \times 10^{4}$ & 6.07 \\
\hline $\mathbf{6}$ & $90 \times 10^{4}$ & 5.95 & $200 \times 10^{4}$ & 6.30 \\
\hline $\mathbf{8}$ & $140 \times 10^{4}$ & 6.14 & $40 \times 10^{5}$ & 6.60 \\
\hline $\mathbf{1 0}$ & $285 \times 10^{4}$ & 6.45 & $70 \times 10^{5}$ & 6.84 \\
\hline $\mathbf{1 2}$ & $60 \times 10^{5}$ & 6.77 & $100 \times 10^{5}$ & 7.00 \\
\hline $\mathbf{2 4}$ & $126 \times 10^{5}$ & $7.10^{*}$ & $150 \times 10^{5}$ & 7.17 \\
\hline $\mathbf{2 6}$ & $124 \times 10^{5}$ & 7.09 & $250 \times 10^{5}$ & 7.39 \\
\hline $\mathbf{2 8}$ & $122 \times 10^{5}$ & 7.08 & $290 \times 10^{5}$ & 7.46 \\
\hline $\mathbf{3 0}$ & $70 \times 10^{5}$ & 6.84 & $300 \times 10^{5}$ & 7.47 \\
\hline $\mathbf{3 2}$ & - & - & $35 \times 10^{6}$ & 7.54 \\
\hline $\mathbf{3 4}$ & - & - & $40 \times 10^{6}$ & 7.60 \\
\hline $\mathbf{4 6}$ & - & - & $55 \times 10^{6}$ & 7.74 \\
\hline $\mathbf{4 8}$ & - & - & $60 \times 10^{6}$ & 7.77 \\
\hline \multicolumn{2}{r}{$*$ Coagulated sample } & & & \\
\hline
\end{tabular}

Table 2. Rate of increase in titratable acidity (\%) during growth of Lactococcus lactis subsp lactis cultivated in sterilized skim milk at $34^{\circ} \mathrm{C}$ and control of culture acidity.

\begin{tabular}{|c|c|c|c|c|}
\hline $\begin{array}{c}\text { Sampling time } \\
\text { (hour })\end{array}$ & Control & $\begin{array}{c}\text { Difference in acid- } \\
\text { ity }\end{array}$ & $\begin{array}{c}\text { With control of culture } \\
\text { acidity }\end{array}$ & $\begin{array}{c}\text { Difference in acid- } \\
\text { ity }\end{array}$ \\
\hline $\mathbf{0}$ & 0.22 & 0.00 & 0.22 & 0.00 \\
\hline $\mathbf{2}$ & 0.25 & 0.03 & 0.25 & 0.03 \\
\hline $\mathbf{4}$ & 0.26 & 0.04 & 0.22 & 0.00 \\
\hline $\mathbf{6}$ & 0.27 & 0.05 & 0.22 & 0.00 \\
\hline $\mathbf{8}$ & 0.28 & 0.06 & 0.23 & 0.01 \\
\hline $\mathbf{1 0}$ & 0.29 & 0.07 & 0.22 & 0.00 \\
\hline $\mathbf{1 2}$ & 0.30 & 0.08 & 0.23 & 0.01 \\
\hline $\mathbf{2 4}$ & $0.53^{*}$ & 0.31 & 0.43 & 0.21 \\
\hline $\mathbf{2 6}$ & 0.61 & 0.39 & 0.30 & 0.08 \\
\hline $\mathbf{2 8}$ & 0.60 & 0.38 & 0.30 & 0.08 \\
\hline $\mathbf{3 0}$ & 0.60 & 0.38 & 0.29 & 0.07 \\
\hline $\mathbf{3 2}$ & - & - & 0.30 & 0.08 \\
\hline $\mathbf{3 4}$ & - & - & 0.32 & 0.10 \\
\hline $\mathbf{4 6}$ & - & - & 0.30 & 0.08 \\
\hline $\mathbf{4 8}$ & - & - & 0.32 & 0.10 \\
\hline
\end{tabular}

* Coagulated sample 

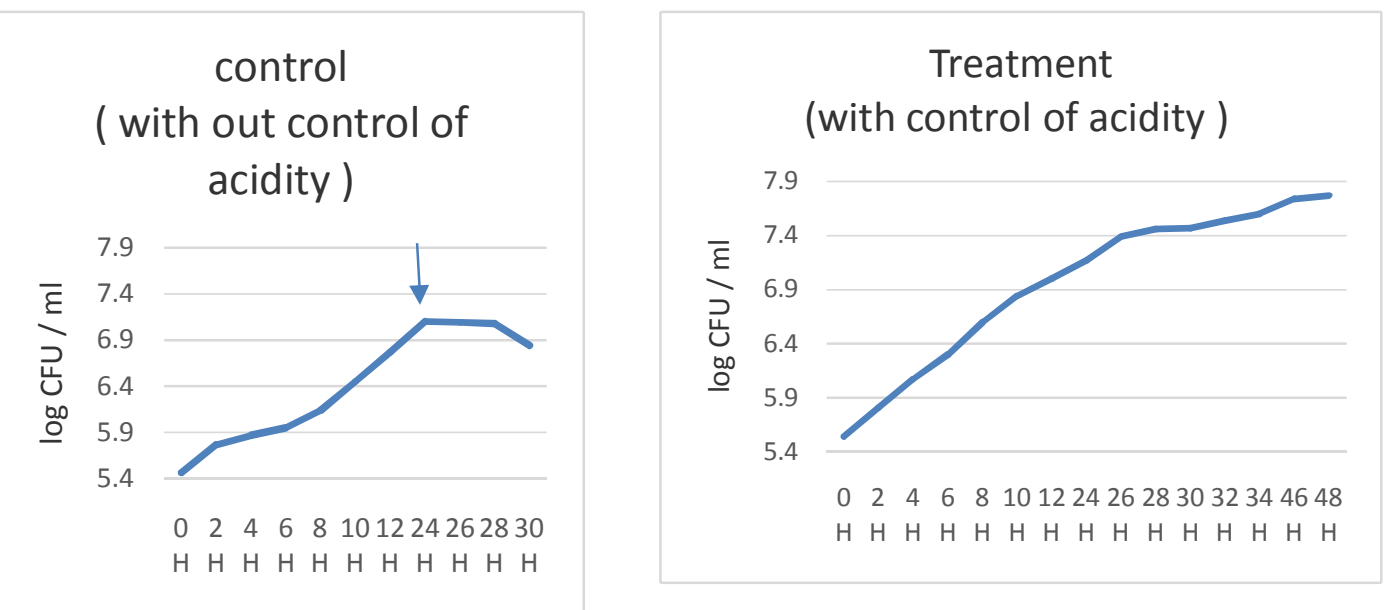

$\downarrow$ coagulated sample .

Fig 1. Rate of increase of colony count $(\log \mathrm{CFU} / \mathrm{ml})$ during growth of Lactococcus lactis subsp lactis cultivated in sterilized skim milk and control of culture acidity at $34^{\circ} \mathrm{C}$.
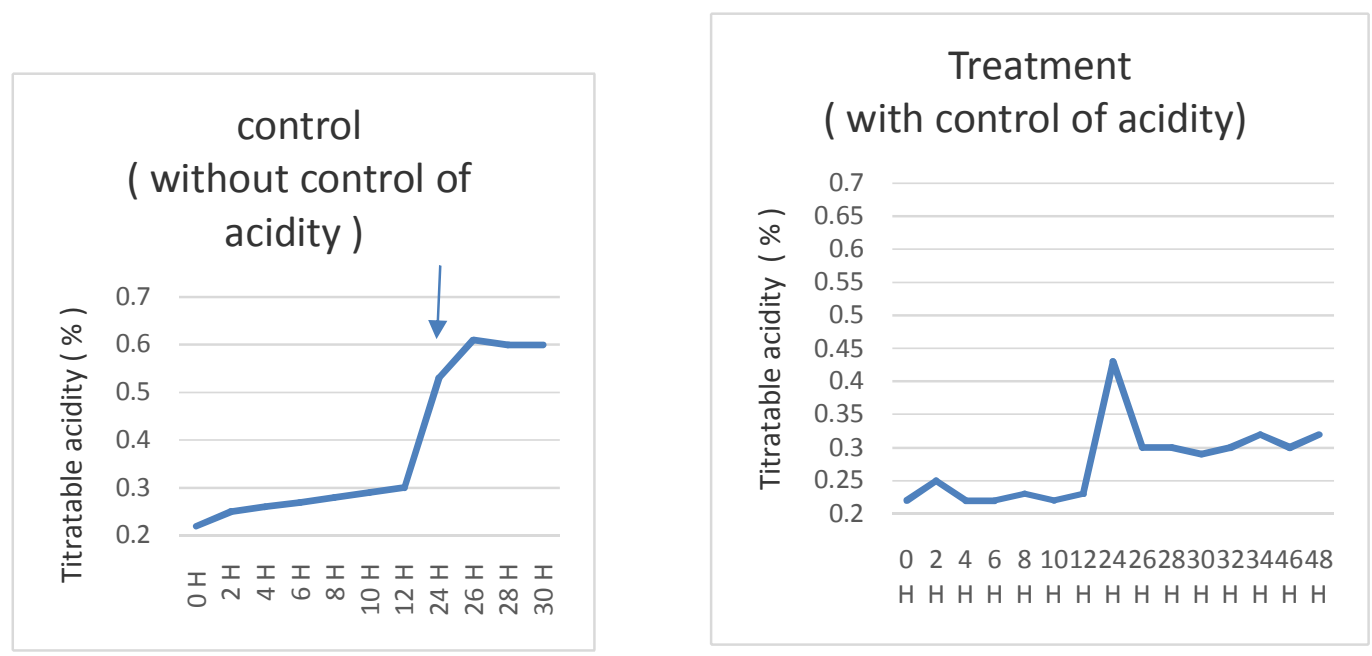

$\downarrow$ coagulated sample .

Fig. 2. Rate of increase in titratable acidity (\%) during growth of Lactococcus lactis subsp lactis cultivated in sterilized skim milk and control of acidity at $34^{\circ} \mathrm{C}$.

\section{Conclusion:}

The obtained results indicated that, when Lactococcus lactis subsp lactis grown in sterilized skim milk, acidity culture control grown by higher specific growth rate and as measured by the rate of increase in colony forming units, in compared with the same variant being growth without control of culture acidity. In addition, it reached a higher maximum cell population compared with the control sample

\section{References}

Bergere, J.L. (1968). Production massive de cellules de Streptococcus lactiques. III- production de differents souches en culture a $\mathrm{pH}$ constant. Le Lait, 48: 131-139.

Blickstad, E. and Molin, G. (1981). Growth and lactic acid production 
of Pseudomonas pentosaceus at different gas environments, temperature, $\mathrm{pH}$ values and nitrite concentration. Eur. J. Appl. Microbiol. Biotechnol., $13: 170-174$.

Bossuyt, R. (1982). A 5-minute ATP platform test for judging the bacteriological quality of raw milk. Neth. Milk Dairy J., 36: 355-364.

Britz, T.J.; J.J. Bezuidenhout; J.M. Dreyer and P.L. Steyn (1980). Use of adenosine triphosphate as an indicator of the microbial counts. South African Journal of Dairy Technology, 12: 89- 91.

Charalampopoulos, D.; S.S. Pandiella and C. Webb (2002). Growth studies of potentially probiotic lactic acid bacteria in cereal-based substrates. Journal of Applied Microbiology 92: 851-859.

Cogan, T.M. (1978). Determination of growth rate of Lactic starter cultures. Irish Journal of Food Science and Technology 2:105-115.

Difco manual (1998). Difco Manual. $11^{\text {th }}$ ed., Difico Laboratories. Division of Becton Dickinson and company, Sparks, Maryland, USA.

Friedman, M.R.A. and E.L. Gaden (1970). Growth and acid production by Lactobacillus delbrueckii in a dialysis culture system. Biotechnol. Bioeng., 12: 962-974.

Hassan, A.I.; N. Deschamps and J. Richard (1989). Precision des measures de vitesse de croissance de Streptococcus Lactiques dans le lait basees sur la method de denombrement microbian par formation de colonies. Etude de reference avic Lactococcus Lactis. Le lait, 69: 433-447.

Ismail, A. (1991). Mass production of lactic acid bacteria growth at constant $\mathrm{pH}$. Assiut Journal of Agriculture Science, Vol. 22: 1, 1991.

Quinto, E.J.; P. Jimenez; I. Caro; J. Tejero and T. Girbes (2014). Probiotic lactic acid bacteria: A Review. Food and Nutrition Sciences, 5: 1765-1775.

Richardson, G.H.; C.A. Ernstrom; J.M. Kim and C. Daly (1983). Proteinase-negative variants of Streptococcus cremoris for cheese starter. J. Dairy Sci., 66: 22782286.

Roy, D.; J. Goulet and A. Le Duy (1986). Bath fermentation of whey ultra-filtrate by Lactobacillus helveticus for lactic acid production. Eur. J. Appl. Microbiol. Biotechnol., 24: 206-213.

Sinclair, N.A. and J.L. Stokes (1962). Fractions which control maximal growth of bacteria. J. Bacteriol., 83: 1147-1154.

Van de Guchte, M.; P. Serror; C. Chervaux; T. Smokvina; D. Ehrlich and E. Maguin (2002). Stress responses in lactic acid bacteria. Antonie Van Leeuwenhoek. 82: 187-216.

Vermeulen, A.; F. Devlieghere; K. Bernaerrts; J. Van Impe and J. Debevere (2007). Growth/no growth models describing the influence of $\mathrm{pH}$, lactic and acetic acid on lactic acid bacteria developed to determine the stability of acidified sauce. International Journal of Food Microbiology, 119: 258-269. 
نمو Lactococcus lactis subsp lactis في اللبن مع التحكم في نسبة الحموضة في المزرعة ،ئس داليا جمال كامل ، نانيس حسنين جمعة ، دينا مصطفي عثمان وعلي اسماعيل حسن فئن

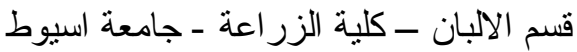

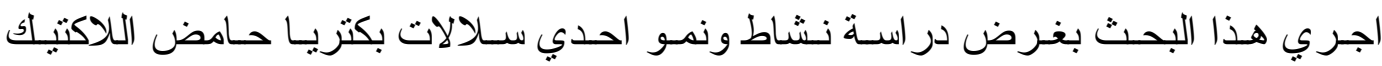

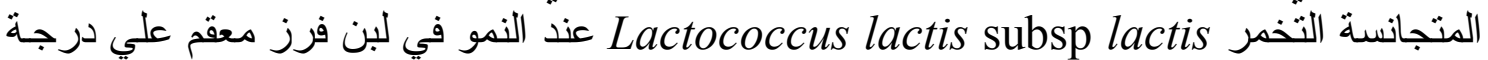

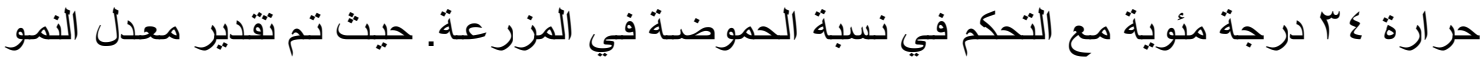

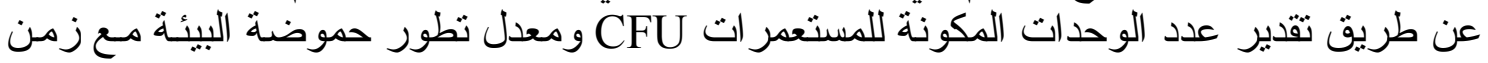

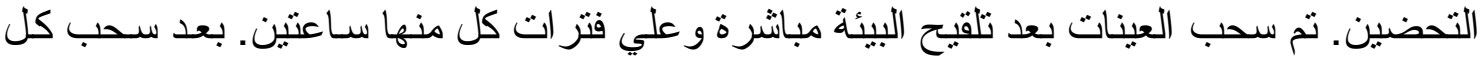

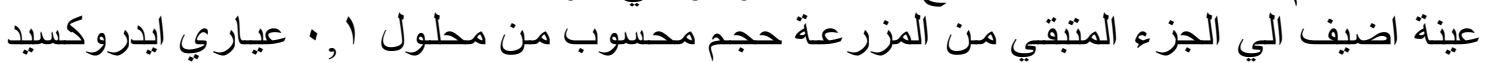

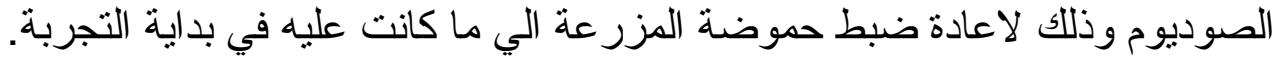
و أكدت النتائج التي تم الحصول طبطول عليها ان:

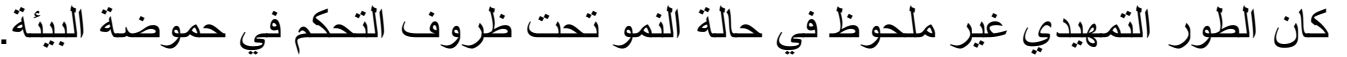

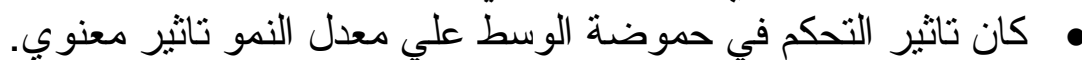

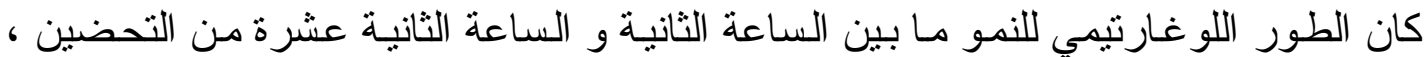

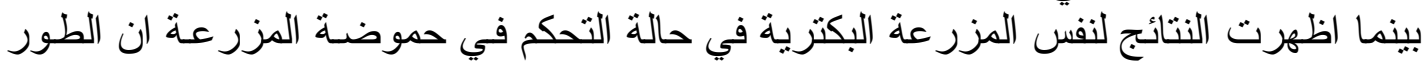

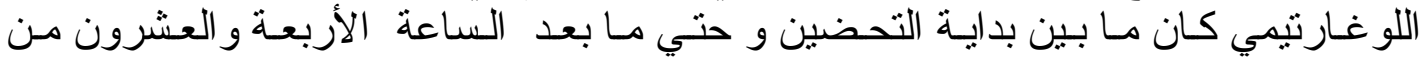

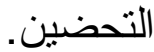

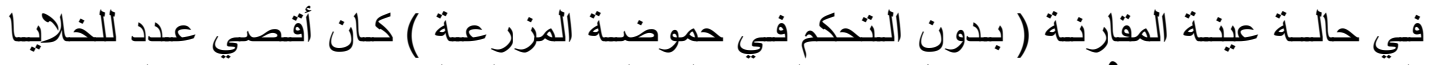

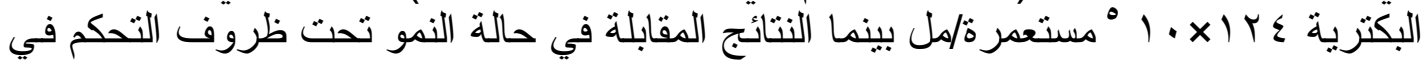

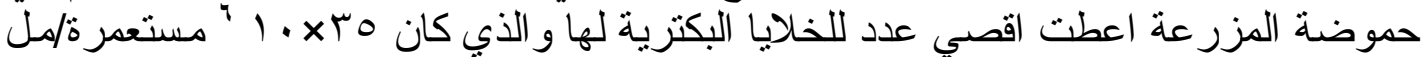
بعد ب ساعة من التحضين. 